Fixed Point Theory, 18(2017), No. 1, 167-190

http://www.math.ubbcluj.ro/ nodeacj/sfptcj.html

\title{
COMMON SOLUTIONS TO SOME SYSTEMS OF VARIATIONAL INEQUALITIES AND FIXED POINT PROBLEMS
}

\author{
B. DJAFARI-ROUHANI* ${ }^{*}$ K.R. KAZMI** AND MOHD. FARID** \\ * Department of Mathematical Sciences, University of Texas at El Paso \\ 500 W. University Ave., El Paso, Texas 79968, USA \\ E-mail: behzad@utep.edu \\ ** Department of Mathematics, Aligarh Muslim University, Aligarh 202002, India \\ E-mails: krkazmi@gmail.com (corresponding author), mohdfrd55@gmail.com
}

\begin{abstract}
In this paper, we introduce an iterative scheme for approximating a common solution to a new system of unrelated split mixed vector variational inequality problems, multivalued variational inequality problems, and common fixed point problem for a family of nonexpansive mappings in a real Hilbert space. We prove a strong convergence theorem for the sequence generated by the proposed iterative scheme. The results presented in this paper generalize and unify previously known results in this area.

Key Words and Phrases: system of unrelated split mixed vector variational inequality problems, system of unrelated multivalued variational inequality problems, common fixed-point problem, iterative scheme.
\end{abstract}

2010 Mathematics Subject Classification: 49J30, 47H10, 47H17, $90 \mathrm{C} 99$.

\section{REFERENCES}

[1] A.S. Antipin, Iterative gradient predictor type methods for computing fixed point of external mappings, in: Parametric Optimization and related topics IV[C] (J. Guddat, H.Th. Jonden, F. Nizicka, G. Still, F. Twitt -Eds.) Peter Lang, Frankfurt Main, 1997, 11-24.

[2] C. Baiocchi, A. Capelo, Variational and Quasi-variational Inequalities, Wiley, New York, 1984.

[3] J.Y. Bello Cruz, A.N. Iusem, A strongly convergent direct method for monotone variational inequalities in Hilbert spaces, Numerical Funct. Anal. Optim., 30(2009), 23-36.

[4] A. Bensoussan, J.L. Lions, Applications of Variational Inequalities to Stochastic Control, NorthHolland, Amsterdam, 1982.

[5] A. Bensoussan, J.L. Lions, Impulse Control and Quasivariational Inequalities, Gauthiers Villers, Paris, 1984

[6] C. Byrne, Y. Censor, A. Gibali, S. Reich, Weak and strong convergence of algorithms for the split common null point problem, J. Nonlinear Convex Anal., 13(2012), 759-775.

[7] Y. Censor, T. Bortfeld, B. Martin, A. Trofimov, A unified approach for inversion problems in intensity modulated radiation therapy, Physics in Medicine and Biology, 51(2006), 2353-2365.

[8] Y. Censor, A. Gibali, S. Reich, Algorithms for the split variational inequality problem, Numer. Algorithms, 59(2012), 301-323.

[9] Y. Censor, A. Gibali, S. Reich, S. Sabech, Common solutions to variational inequalities, SetValued Var. Anal., 20(2012), 229-247. 
[10] P.L. Combettes, The convex feasibility problem in image recovery, Adv. Imaging Electron Phys., 95(1996), 155-270.

[11] J. Crank, Free and Moving Boundary Problems, Clarendon Press, Oxford, 1984.

[12] G. Crombez, A hierarchical presentation of operators with fixed points on Hilbert spaces, Numerical Funct. Anal. Optim., 27(2006), 259-277.

[13] G. Crombez, A geometrical look at iterative methods for operators with fixed points, Numerical Funct. Anal. Optim., 26(2005), 157-175.

[14] P. Daniele, F. Giannessi, A. Maugeri (eds.), Equilibrium Problems and Variational Models, Including Papers from the Meeting held in Erice, June 23-July 2, 2000, Nonconvex Optimization and Its Applications, vol. 68, Kluwer Academic, Norwell, 2003.

[15] B. Djafari-Rouhani, K.R. Kazmi, S.H. Rizvi, A hybrid-extragradient-convex approximation method for a system of unrelated mixed equilibrium problems, Trans. on Mathematical Programming and Applications, 1(8)(2013), 82-95.

[16] G. Duvaut, J.L. Lions, Inequalities in Mechanics and Physcis, Springer-Verlag, Berlin, 1976.

[17] G. Fichera, Problemi elastostatici con vincoli unilaterali: Il problema di Signorini ambigue condizione al contorno, Attem. Acad. Naz. Lincei. Mem. Cl. Sci. Nat. Sez. Ia, 7(8)(1963/64), 91-140.

[18] F. Giannessi, Theorem of alternative, quadratic program and complementarity problems. In: Variational Inequality and Complementarity Problems (R.W. Cottle, F. Giannessi, J.L. Lions -Eds.) Wiley, New York, 1980, 151-186.

[19] F. Giannessi (Ed.), Vector Variational Inequalities and Vector Equilibria, Mathematical Theories, Nonconvex Optimization and Applications, vol. 38, Kluwer Academic, Dordrecht, 2000.

[20] F. Giannessi, A. Maugeri, P.M. Pardalos (Eds.), Equilibrium Problems: Nonsmooth Optimization and Variational Inequality Methods, Nonconvex Optimization and Its Applications, vol. 58. Kluwer Academic, Dordrecht, 2001.

[21] R. Glowinski, Numerical Methods for Nonlinear Variational Problems, Springer, Berlin, 1984.

[22] K. Goebel, W.A. Kirk, Topics in Metric Fixed Point Theory, Cambridge Studies in Advanced Mathematics, 28, Cambridge University Press, Cambridge, 1990.

[23] X.H. Gong, H.M. Yue, Existence of efficient solutions and strong solutions for vector equilibrium problems, J. Nanchang Univ., 32(2008), 1-5.

[24] K.R. Kazmi, S.H. Rizvi, Iterative approximation of a common solution of a split generalized equilibrium problem and a fixed point problem for nonexpansive semigroup, Mathematical Sciences, 7, Art. 1 (2013) Doi 10.1186/2251-7456-7-1.

[25] K.R. Kazmi, S.H. Rizvi, An iterative method for split variational inclusion problem and fixed point problem for a nonexpansive mapping, Optimization Letters, 8(3)(2014), 1113-1124.

[26] K.R. Kazmi, Split nonconex variational inequality problem, Mathematical Sciences, 7, Art. 36 (2013) (doi: 10.1186/10.1186/2251-7456-7-36).

[27] K.R. Kazmi, Split general quasi-variational inequality problem, Georgian J. Math., 22(3) (2015), 385-392.

[28] N. Kikuchi, J.T. Oden, Contact Problems in Elasticity, SIAM, Philadelphia, 1998.

[29] D.T. Luc, Theory of Vector Optimization Lecture Notes in Economics and Mathematical Systems, 319, Springer-Verlag, Berlin, 1989

[30] A. Moudafi, Split monotone variational inclusions, J. Optim. Theory Appl., 150(2011), 275-283.

[31] N. Nadezhkina, W. Takahashi, Strong convergence theorems by a hybrid method for nonexpansive mappings and Lipschitz continuous monotone mappings, SIAM J. Optim., 16(2006), 1230-1241.

[32] J.T. Oden, E.B. Pires, Contact problems in elastostatics with nonlocal friction laws, TICOM, Report 81-12, University of Texas, Austin, 1981.

[33] Z. Opial, Weak convergence of the sequence of successive approximations for nonexpansive mappings, Bull. Amer. Math. Soc., 73(1967), no. 4, 595-597.

[34] S.Q. Shan, N.J. Huang, An iterative method for generalized mixed vector equilibrium problems and fixed point of nonexpansive mappings and variational inequalities, Taiwanese J. Math., 16(2012), no. 5, 1681-1705. 
[35] G. Stampacchia, Formes bilinearires coercitives sur les ensembles convexes, C.R. Acad. Sci. Paris, 258(1964), 4413-4416.

[36] N.X. Tan, On the existence of solution of quasivariational inclusion problems, J. Optim. Theory Appl., 123(2004), 619-638.

Received: April 4, 2014; Accepted: February 19, 2015. 